\title{
STRIKES AND THE PRESS IN THE NORTH-EAST, 1815-44: A NOTE
}

Maurice Milne's article ${ }^{1}$ restricts its discussion of press treatment of industrial disputes in this period to an analysis of coverage of three strikes in three Newcastle upon Tyne papers. He passes from this review to the following conclusion:

The facile assumption that radical political beliefs would predispose their holder to espouse the cause of organised labour will not stand up to close scrutiny, at least where one important industrial region and its newspapers are concerned.

Readers should beware the equation of Newcastle with the whole "important industrial region" and three selected titles with the whole range of "its newspapers".

The choice of the Newcastle Courant, Newcastle Chronicle and Tyne Mercury may give the impression ${ }^{2}$ that these were the only papers published either in Newcastle or in the North-East at the period. They were the only three published in Newcastle in 1815, as Milne states (p. 226), but by 1844 a further four papers had made their appearance in the town. ${ }^{3}$ On Tyneside (i.e. published at Gateshead and Tynemouth) another three titles were published by $1844^{4}$ - making a total of ten Tyneside papers by the latter date -, while in the "region" (defined here as the counties of

1 "Strikes and strike-breaking in North-East England, 1815-44: The attitude of the local press", in: International Review of Social History, XXII (1977).

2 Unintentionally: Maurice Milne is the author of a book about the newspapers of the area, The Newspapers of Northumberland and Durham (Newcastle upon Tyne, 1971).

3 The Newcastle Journal (starting in 1832), the Newcastle Press (1833) and Newcastle Standard (1836), two short-lived radical papers, and the Northern Liberator (1837-40). This number excludes three less general periodicals, the Anti-Monopolist (1844), the English Non-Intrusionist (1843) and the London Coal Market / Prices of Coals on the London Coal Market (1822). All the titles referred to here are taken from the British Museum Catalogue and the list does not claim to be exhaustive.

4 The Gateshead Observer (1837), the Northumberland Advertiser (1831) and the Port of Tyne Pilot (1839). 
Northumberland and Durham) during this period a total of eight more were available (published in Sunderland, Durham and Berwick). ${ }^{5}$ Not all these papers became long-term commercial propositions, but several already were so, and others survived into the present century. This list of locally produced papers should, moreover, be expanded by the output of more distant presses, not least that of the leading radical presses, such as the Leeds Northern Star, which carried regular reports of activities on Tyneside. Thus in April 1839, a meeting at Hartley, in Northumberland, "before it separated formed a Reading Room, and ordered the Radical journals", taking a room in partnership with the local Working Men's Association to accommodate it. ${ }^{6}$ Here at least we may assume "the average keelman or miner" was not "sadly out of place" (Milne, p. 239): the importance of reading rooms in the context of expensive newspapers, and especially for the less affluent, must not be overlooked in calculating the influence of those newspapers and their political principles. ${ }^{7}$ Alternative accounts of the events discussed by Maurice Milne were available.

He proceeds to the discussion after making the following statement:

At various times during the nineteenth century, working men could rely upon certain newspapers to give sympathetic coverage of their struggles with employers. The unstamped papers of the 1830's and the Bee-Hive of the sixties and seventies are obvious examples. These were essentially "fringe" newspapers, however, not the normal reading-matter of the general newspaper-buying public. (p. 226)

His central interest is in the question, "In particular, was the politically radical press more likely than other branches of the press to identify with working people in their economic struggles?" (p. 226). He goes on to speak of the establishment of "the Mercury's claim to be regarded as a radical newspaper in political matters" (p. 228); it was "the paper which espoused the popular cause" (p. 235); "it had placed itself in the vanguard of political reform, proclaiming the cause of the people" (p. 236), a "model for some, at least, of the moderately radical newspapers published in provincial centres" (p. 238), and simply "the radical Tyne Mercury" (p. 240). The effect of these phrases, unintentionally, perhaps, is to imply that

5 The Sunderland Beacon / Northern Times (1838), the Sunderland \& Durham General Shipping Gazette (1831 only), the Sunderland Herald (1831) and Sunderland Mirror (1839); the Durham County Advertiser (1814) and Durham Chronicle (1820); the Berwick Advertiser (1825) and Berwick \& Kelso Warder (1835).

6 Northern Liberator, 20 April 1837.

7 The literature on social access to reading matter and the public reading of newspapers in the period is reviewed in P. Corrigan and V. Gillespie, Class struggle, social literacy and idle time: The provision of public libraries in England (Brighton, 1978). 
the Mercury was the area's only radical voice for the period 1815-44, and that an examination of $i t s$ treatment of "economic struggles" will inform us of the treatment of the "politically radical press" as a whole. While it is impossible in the present note to discuss the political and other commitments of all the contemporary papers mentioned above (beyond noting that none, at any rate, were unstamped), one in particular demands attention in the context of this emphasis on a paper claiming to be radical.

Two articles by W. H. Maehl were published in this Review in 1963 and $1969,{ }^{8}$ and one by D. J. Rowe in $1971,{ }^{9}$ which discuss, from different points of view, the strength and activities of the Chartists in the North-East, one of the main foci of political and journalistic attention in the period under discussion. Both these writers give considerable weight to the influence of the Northern Liberator newspaper in these activities, and there can be no doubt that an alternative radical newspaper existed in Newcastle, at least for three crucial years between 1815 and 1844. Although at first sight the Liberator may appear to fall into the category of "fringe' newspapers", it was not unstamped on the one hand, being legally stamped at one penny throughout its career, and it cannot be entirely excluded from the category "normal reading-matter of the general newspaper-buying public" on the other.

We have some information about the "respectability" of the supporters of Tyneside Chartism, at least in the early stages, from Rowe's article (cited above), where it is pointed out that the proprietor of the Liberator from early $1838,{ }^{10}$ Robert Blakey, was "a prosperous furrier, who had been

8 W. H. Maehl, Jr, “Augustus Hardin Beaumont: Anglo-American radical (1798-1838)", in: International Review of Social History, XIV (1969), and "Chartist disturbances in Northeastern England, 1839", ibid., VIII (1963).

9 D. J. Rowe, "Some aspects of Chartism on Tyneside", ibid., XVI (1971). Maehl's reply to this is contained in his "The dynamics of Chartism: A case-study in Northeastern England", in: Albion, VII (1975), esp. pp. 103-05. Rowe cites his evidence in his article as follows: "The Home Office Papers are the source of many of the references in this article. In order to avoid over-loading it with foot-notes such references are unacknowledged. The main categories are $\mathrm{HO} 40 / 42$ and $40 / 46$." (p. 20, note 1) His remarks on the intellectual capacities of working-class people, "Provision stores and temperance associations dealt with practical matters which could hold the attention of working men Chartism, by contrast, was a theoretical concept which had to build up to something tangible if it was to retain interest" (although "interest in British foreign policy acted as a diversion from Chartism") (p. 35), are ill-considered. They take no account of either the contribution of working women to exclusive trading and other activities (cf. Port of Tyne Pilot, 25 May 1839: a meeting of Chartists' wives), or the level of analysis and debate evidenced in reports and contributions to the Northern Liberator.

10 Maehl, "Augustus Hardin Beaumont", p. 249, tells us Beaumont sold it on 1 January 1838 , but the notice of publication in the paper itself indicates a "caretaker" period in the hands of Arthur James Beaumont until 29 March. 
mayor of Morpeth in 1836-7. Blakey was a writer of some eminence and was to become Professor of Logic and Metaphysics at the Queen's University, Belfast" (p. 22). Another mayor, this time of Newcastle itself, John Fife, is mentioned as an active supporter, and Rowe lists representatives of several trades, including "the owner of a prosperous bookshop" and several skilled craftsmen, in his demonstration that the movement's support was by no means derived from pitmen or unskilled workers alone. ${ }^{11}$ Mayors at least we may take to be part of the "general newspaper-buying public". The paper was also read, of course, by those who were anything but supporters of Chartism. ${ }^{12}$ So far as the quantity of readers rather than their "quality" is concerned, in judging the Liberator's possible claim to be a "normal" paper, we may note the evidence of the Newspaper Stamp returns. ${ }^{13}$ Over the period in which the Liberator was published, October 1837 to December 1840, an average of 3,494 were issued to the Newcastle Courant, 3,270 to the Newcastle Chronicle and 714 to the Tyne Mercury each week, while 1,881 were issued to the Northern Liberator. ${ }^{14}$ Even allowing for a margin of error of $100 \%$ in these returns, then, the Liberator qualifies as "normal" in circulation terms, if the Mercury does.

The Liberator was a Chartist newspaper, and its treatment of almost every issue was different from that of the three surveyed by Milne, including that of "working people in their economic struggles". Thus it campaigned for support of the Glasgow Cotton Spinners throughout late

11 Rowe, loc. cit., p. 23. Fife by the summer of 1839 was certainly disenchanted. He led the "respectable" opposition to Chartism in Newcastle, cf. Northern Liberator, 27 July, 29 August 1839, etc., and Fife's correspondence with Lord John Russell quoted in Maehl, "The dynamics of Chartism", pp. 112ff. Rowe has also compiled a list of "known Tyneside Chartists", which excludes the pit and other villages in the hinterland of Durham and Northumberland, published in the Bulletin of the North-East Group for the Study of Labour History, No 8 (1974). Here again the range of occupations is striking. 12 The Poor Law Assistant Commissioner for the area, Sir John Walsham, mentioned it feelingly in reports to Headquarters (e.g., Public Record Office, MH 32/77, 30 March and 1 August 1838), where Beaumont's influence was taken seriously (Chadwick to Lord John Russell, 1 February 1838, Chadwick Manuscripts 1733, University College, London).

13 A source not without defects. It is accepted, however, by Patricia Hollis (The Pauper press (London, 1970), p. 146), by S. Maccoby ("Newspaper politics: A footnote to nineteenth-century history", in: Politica, I (1934)), and, not least, by the Northern Liberator (27 January and 26 May 1838) and other local papers (e.g., Port of Tyne Pilot, 4 January 1840). Whatever their drawbacks as an absolute guide to numbers of readers, they may be regarded as a meaningful guide to relative sales as between different titles.

14 These figures are derived from the Parliamentary "Returns of the Numbers of Stamps issued [...] for all newspapers in Great Britain and Ireland" (later "the several newspapers in England, Scotland and Wales"): for the period 30 June 1837 to 31 March 1838, Parliamentary Papers, 1837-38, XXXVI; for the quarters of 1838, 1839, XXX; for the quarters of 1839,1840, XXIX; for the quarters of 1840,1841 , XIII. 
1837 and 1838, for the formation of a local Anti-Poor-Law Association (27 January 1838), for the Chinese in the preliminary rounds of the Opium War (1 November 1839), and for the Canadians in their rebellion of 1837 (6 January 1838), as well as for the Charter. Although none of the major disputes discussed in Milne's article took place during the Liberator's lifetime, we may discern its attitude to such economic struggles in its treatment of other examples. On the most general level, the economic radicalism of its founder, A. $\mathrm{H}$. Beaumont, as shown in his election address during the election campaign of 1837 , may serve as an indication. Maehl tells us:

He proposed to provide full employment at reasonable wages by nationalization of railways, canals and other large public works, so that "any man who was turned off work elsewhere might apply to the national and comprehensive company with a certainty of success."15

It need not surprise us, then, that the Liberator carried items such as that published on 28 September 1839, an exposition of wages as the reproduction-cost of labour-power. The paper's attitude to the Pitmen's Union and its leader contrasted strongly with the Mercury's, as may be seen from its accounts of Hepburn's speeches (e.g., 6 January, 30 June, 15 September, 9 and 27 October 1838), and from its report of the "Great Meeting on the Black Fell" of representatives of twenty collieries, to resist the coal-owners' proposal to alter the date of Binding from October to January (when the miners' bargaining power was less). ${ }^{16}$ Similarly the issue of 16 February 1839 contains a report deploring the imposition of stringent regulations on the miners at Cramlington Colliery: they were paid by the amount of coal they produced, and a peck of "small" (small coal or stone) in a sevenhundred-weight corf rendered the whole corf forfeit to the owner without pay. The same issue reports the formation of a branch of the Northern Political Union in Cramlington, with some satisfaction.

The only notable strike which took place while the Liberator was published was in August 1839, when miners in some collieries observed the "national holiday". This example throws some light on the contemporary significance of drawing a line between political and economic principles or action: the use of a strike to further political objectives in itself demonstrates the link in Chartists' minds. The Liberator, of course, supported them, and reported in detail their stand, the attacks by the military, the arrests and the prison sentences which followed, its position once again

15 Maehl, "Augustus Hardin Beaumont", p. 247, quoting from the Newcastle Courant, 28 July 1837.

1624 February 1838, cf. Rowe, loc. cit., p. 24. 
being in marked contrast to that of the Mercury as well as of the other papers surveyed in Milne's article. During the trial of six of the miners involved in the strike - their offence, "the accused had several times refused to go to work", was theoretically merely breach of contract (their Bond to work for the coal-owner for a year) - one of the accused attempting to give a defence of their action in political terms was told by the magistrate that it was irrelevant. Not so, however, the contribution of the coal-owner, John Jobling, who gave evidence as follows: "He considered that the conduct of some of them had led to the character for Radical principles, which had been given to that neighbourhood, a character which, he regretted to say was not undeserved". Three were discharged from their Bond, as Jobling said, "he wished to get clear of Bell, Emery and Green [...]. They were not even content with attending meetings themselves, but actually brought their wives with them"; the others were sentenced to terms in prison with hard labour. ${ }^{17}$

A similar link between economics and politics was made by the supporters of the North of England Working Men's Joint Stock Provision Stores, founded with strong encouragement from the Liberator in 1839 (14 April, 28 September, 5 October and 13 December). The report of the formation of the North Shields branch concludes as follows: "The men of North Shields are the right sort of men [...]. they now see that Whig aristocrats will do nothing like justice to the country, and henceforth they will stand by their order - the order of honest working men." (6 December) Theirs was a similar enterprise to that of the Chartists who engaged in exclusive dealing: ${ }^{18}$ both were seen to be a form of political as well as economic action. Having no vote, of course, the Chartists had no direct political weapons.

This brief note is intended simply to remind readers of Milne's article that the three newspapers he surveys were not the only ones available on Tyneside in the period, nor the Mercury the only representative of the "politically radical press [.. . ] likely [.. .] to identify with working people" (p. 226). It is no surprise that the Northern Liberator supported Chartists, strikers and co-operators, any more than that the other papers did not. For them, as Milne says, "It would have been folly to antagonise subscribers and advertisers by forthrightly championing the men against their masters", and not until the Liberator's aims had so far been achieved that "the men possessed the franchise and enjoyed the means and opportunity to become regular newspaper readers" could "a provincial paper [...] take their side" (p. 239).

17 Northern Liberator, 31 August 1839.

18 Cf. ibid., 1 June; Port of Tyne Pilot, 25 May. 